\title{
Lack of detectable allergenicity of transgenic maize and soya samples
}

\author{
Rita Batista, BSc, ${ }^{\text {a,b }}$ Baltazar Nunes, MSc, ${ }^{a}$ Manuela Carmo, ${ }^{\text {a }}$ Carlos Cardoso, PharmD, ${ }^{c}$ \\ Helena São José, ${ }^{c}$ António Bugalho de Almeida, MD, PhD, ${ }^{d}$ Alda Manique, MD, ${ }^{d}$ \\ Leonor Bento, MD, PhD, ${ }^{\mathrm{e}}$ Cândido Pinto Ricardo, PhD, ${ }^{\mathrm{b}, \mathrm{f}}$ and Maria Margarida \\ Oliveira, $\mathbf{P h D}^{\mathbf{b}, \mathbf{g}}$ Lisboa, Oeiras, and Algés, Portugal
}

Background: The safety issues regarding foods derived from genetically modified (GM) plants are central to their acceptance into the food supply. The potential allergenicity of proteins newly introduced in GM foods is a major safety concern.

Objective: We sought to monitor, in potentially sensitive human populations, the allergenicity effects of 5 GM materials obtained from sources with no allergenic potential and already under commercialization in the European Union. Methods: We have performed skin prick tests with protein extracts prepared from transgenic maize (MON810, Bt11, T25, Bt176) and soya (Roundup Ready) samples and from nontransgenic control samples in 2 sensitive groups: children with food and inhalant allergy and individuals with asthmarhinitis. We have also tested IgE immunoblot reactivity of sera from patients with food allergy to soya (Roundup Ready) and maize (MON810, Bt11, Bt176) samples, as well as to the pure transgenic proteins (CryIA[b] and CP4 5-enolpyruvylshikimate3-phosphate synthase).

Results: None of the individuals undergoing tests reacted differentially to the transgenic and nontransgenic samples under study. None of the volunteers tested presented detectable IgE antibodies against pure transgenic proteins.

Conclusion: The transgenic products under testing seem to be safe in terms of allergenic potential. We propose postmarket testing as an important screening strategy for putative allergic sensitization to proteins introduced in transgenic plants. (J Allergy Clin Immunol 2005;116:403-10.)

Key words: Transgenic food, allergenicity, immune response, public health, food safety, recombinant DNA technology

From ${ }^{a}$ Instituto Nacional de Saúde Dr Ricardo Jorge, Lisboa; ${ }^{\mathrm{b}}$ Instituto de Tecnologia Química e Biológica/Instituto de Biologia Experimental e Tecnológica, Oeiras; ${ }^{\mathrm{c} C l}$ Clínica Médica e de Diagnóstico Dr Joaquim Chaves, Algés; ${ }^{\mathrm{d}}$ Clínica Universitária de Pneumologia do Hospital de Santa Maria, Lisboa; ${ }^{\mathrm{e}}$ Departamento de Clínica Pediátrica do Hospital de Santa Maria, Lisboa; ${ }^{\mathrm{f}}$ Instituto Superior de Agronomia, Tapada da Ajuda, Lisboa; and ${ }^{g}$ Departamento Biologia Vegetal, Faculdade de Ciências de Lisboa, Lisboa.

Supported by Fundação Calouste Gulbenkian, research project SDH.SP.I.01.11 and by Comissão de Fomento da Investigação em Cuidados de Saúde, research project no. 186/01.

Received for publication January 11, 2005; revised March 22, 2005; accepted for publication April 12, 2005

Available online June 1,2005.

Reprint requests: Rita Batista, BSc, Instituto Nacional de Saúde Dr Ricardo Jorge, Av Padre Cruz, 1649-016 Lisboa, Portugal; E-mail: rbatista@ itqb.unl.pt.

0091-6749/\$30.00

(c) 2005 American Academy of Allergy, Asthma and Immunology doi:10.1016/j.jaci.2005.04.014

\section{Abbreviations used}

Bt: Bacillus thuringiensis

EPSPS: 5-Enolpyruvylshikimate-3-phosphate synthase

GM: Genetically modified

GMO: Genetically modified organism

PAT: Phosphinotricine acetyl transferase

RUR: Roundup Ready

SPT: Skin prick test

Recombinant DNA technology or genetic engineering allows the transfer of single genes from one organism to another, even if distantly related, a feat impossible through conventional plant breeding. As a result, a genetically modified organism (GMO) will contain a modified or additional trait encoded by the introduced gene or genes, which generally results in additional proteins.

Potential benefits for world agriculture derived from GMOs could be enormous, including the possibility of producing higher yields of more nutritious food in more sustainable regimens. ${ }^{1-5}$

With the development of the new modification techniques, there is the increasing concern of emergence of new food allergies. An example of such a situation is the Brazil nut allergen (2S protein), which when overexpressed in soybean was found to retain its allergenicity and was therefore never commercialized. ${ }^{6}$

Food allergy is a term that should be used to describe adverse reactions to certain foods because of immunologic mechanisms. ${ }^{7}$ The majority of individuals with documented immunologic reactions to foods exhibit IgE-mediated hypersensitivity reactions that can be sudden, severe, and life-threatening. ${ }^{8}$ The best estimates are that IgE-mediated food allergies affect approximately $1 \%$ to $2 \%$ of the adult population ${ }^{9,10}$; in children this value is estimated to be $2 \%$ to $8 \%$. $^{11,12}$

Before market introduction, genetically modified (GM) food products are subjected to extensive assessment of potential effects to human health, including toxicity and potential allergenicity. When the gene source is an allergenic food, in vitro and clinical tests are available to assess the allergenicity of the transferred protein or proteins. However, most genes transferred through genetic engineering are obtained from organisms with no allergenic history. In such cases the assessment of allergenicity becomes more difficult to obtain because of the absence of valid methods and models. ${ }^{13-16}$ 
TABLE I. Transgenic flour products tested in SPTs and in IgE Immunoblot reactivity assays

\begin{tabular}{|c|c|c|c|c|c|}
\hline Material & Characteristics & $\begin{array}{c}\text { Date of } \\
\text { commercialization }\end{array}$ & $\begin{array}{l}\text { Responsible } \\
\text { company }\end{array}$ & $\begin{array}{l}\text { Origin and } \\
\text { certification of } \\
\text { the material }\end{array}$ & $\begin{array}{l}\text { Method of testing } \\
\text { and human } \\
\text { population studied }\end{array}$ \\
\hline $\begin{array}{l}2 \% \mathrm{GM} \\
\mathrm{Bt} 11 \text { maize }\end{array}$ & $\begin{array}{l}\text { Insect resistance (CryIA[b] } \\
\text { gene) and ammonium } \\
\text { glufosinate tolerance } \\
\text { (PAT gene); 35S pro; } \\
\text { NOS 3' t }\end{array}$ & 1998 & Syngenta & $\begin{array}{l}\text { Institute of Reference } \\
\text { Materials and } \\
\text { Measurements } \\
\text { certified }\end{array}$ & $\begin{array}{l}\text { SPTs in a population } \\
\text { of allergic children } \\
\text { ( } 27 \text { individuals); } \\
\text { IgE immunoblot } \\
\text { reactivity assay with sera } \\
\text { from patients with food } \\
\text { allergy ( } 57 \text { individuals) }\end{array}$ \\
\hline $\begin{array}{l}\text { 100\% GM } \\
\text { Bt176 maize }\end{array}$ & $\begin{array}{l}\text { Insect resistance (CryIA[b] } \\
\text { gene) and ammonium } \\
\text { glufosinate tolerance } \\
\text { (PAT gene); 35S pro; 35S t }\end{array}$ & 1997 & Syngenta & & $\begin{array}{l}\text { SPTs in a population } \\
\text { of allergic children } \\
\text { ( } 27 \text { individuals); } \\
\text { IgE immunoblot } \\
\text { reactivity assay with } \\
\text { sera from patients } \\
\text { with food allergy } \\
\text { (57 individuals) }\end{array}$ \\
\hline $\begin{array}{l}100 \% \text { GM } \\
\text { T25 maize }\end{array}$ & $\begin{array}{l}\text { Ammonium glufosinate } \\
\text { tolerance (PAT gene); } \\
\text { 35S pro; } 35 \mathrm{~S} \mathrm{t}\end{array}$ & 1998 & $\begin{array}{c}\text { Bayer Crop } \\
\text { Sciences }\end{array}$ & $\begin{array}{l}\text { National Service of } \\
\text { Plant Protection } \\
\text { (DGPC); not certified }\end{array}$ & $\begin{array}{l}\text { SPTs in a population of } \\
\text { patients with asthma- } \\
\text { rhinitis (50 individuals) }\end{array}$ \\
\hline $\begin{array}{l}\text { 100\% GM } \\
\begin{array}{l}\text { MON810 } \\
\text { maize }\end{array}\end{array}$ & $\begin{array}{r}\text { Insect resistance (CryIA[b] } \\
\text { gene); } 35 \mathrm{~S} \text { pro; } \mathrm{NOS3}^{\prime} \mathrm{t}\end{array}$ & 1998 & Monsanto & & $\begin{array}{l}\text { SPTs in a population } \\
\text { with asthma-rhinitis } \\
\text { (50 individuals); IgE } \\
\text { immunoblot reactivity } \\
\text { assay with sera from } \\
\text { patients with food allergy } \\
\text { ( } 24 \text { of the } 57 \text { individuals) }\end{array}$ \\
\hline $\begin{array}{l}5 \% \text { GM } \\
\text { RUR soya }\end{array}$ & $\begin{array}{r}\text { Gliphosate resistance } \\
\text { (CP4EPSPS gene); } \\
\text { 35S pro; NOS 3' t }\end{array}$ & 1996 & Monsanto & $\begin{array}{l}\text { Institute of Reference } \\
\text { Materials and } \\
\text { Measurements } \\
\text { certified }\end{array}$ & $\begin{array}{l}\text { SPTs in a population of } \\
\text { allergic children ( } 27 \\
\text { individuals); IgE } \\
\text { immunoblot reactivity } \\
\text { assay with sera from } \\
\text { patients with food allergy } \\
\text { (57 individuals) }\end{array}$ \\
\hline
\end{tabular}

$35 S$ pro, 35S Cauliflower Mosaic Virus promoter; $35 \mathrm{~S} t$, $35 \mathrm{~S}$ Cauliflower Mosaic Virus terminator; NOS 3' $t$, Agrobacterium tumefaciens nopaline synthase terminator; $D G P C$, Direcçao Geral de Protecção de Culturas.

In this study we have monitored the $\operatorname{IgE}$ response of allergy-sensitive populations to GM maize and soya products (Table I). The transgenes in maize and soya were obtained from sources with no allergenic history and approved for human consumption in the European Union. The $\mathrm{IgE}$ response of the same individuals to nonmodified products was also analyzed for comparison.

\section{METHODS}

This study was evaluated and approved by the Research Ethic Committees of the Hospital of Santa Maria and the National Institute of Health, Lisbon, Portugal. All individuals participating in this study or their parents also provided informed consent.

\section{Food inquiry}

Because of the fact that IgE-mediated allergic reactions require prior exposure, resulting in sensitization, we have performed a food inquiry to evaluate the consumption of soya and maize food-derived products. Bearing in mind that since 1998 all the GM products under testing were approved for commercialization in the European Union (Table I), we assumed that consumption of maize and soya food-derived products implied a consumption of GM soya and maize.

The food inquiry was performed on 106 healthy volunteers to find out which maize- and soya-derived products (from a list of 205 different products) they had already consumed. The population studied included individuals with ages from 1 to 41 years, with an average of 12.4 years (48 male and 58 subjects).

\section{Transgenic quality of the noncertified flour samples}

In addition to the 3 noncertified transgenic products listed in Table I, nontransgenic analogues were also tested as controls. For the noncertified material (Table I), we have first confirmed the transformation event and the absence of cross-contamination among them.

For these analyses, DNA was isolated by using the cetyltrimethylammonium bromide method, ${ }^{17}$ with 3 replicas per sample. DNA quality and concentration were analyzed by means of agarose gel electrophoresis, and maize-specific amplifiable DNA was detected by using PCR amplification of a 226-bp sequence from the maize invertase gene. $^{18}$

The presence or absence of the 35S Cauliflower Mosaic Virus promoter in the transgenic (Table I) and control samples was checked 
by using standard protocols for the amplification of a 195-bp DNA sequence. ${ }^{18}$

Transformation event-specific PCR reactions were performed to verify the presence of MON810, T25, and Bt176 transgenic events. ${ }^{18}$ Different internal controls were always used to detect putative contaminations. In each case whole or digested (HaeIII or HinfI) PCR product size was compared with expected values. ${ }^{18}$

\section{Preparation of protein extracts for human skin prick testing and IgE immunoblot reactivity}

Maize and soya protein extracts were made by Laboratorios Leti, SL (Madrid, Spain) according to approved pharmaceutical preparative and safety procedures for the production of diagnostic skin prick test (SPT) materials. About $10 \mathrm{~g}$ of each of the maize and soya flour samples was extracted for 16 hours in 1:20 (wt/vol) PBS (pH 7.4). After centrifugation, the pellet was discarded, and the supernatant was extensively dialyzed against bidistilled water. The extracts were centrifuged, filter sterilized, and freeze-dried. For human SPTs, the extracts were resuspended to $10 \mathrm{mg} / \mathrm{mL}$ maize or soya freeze-dried material (approximately $2 \mathrm{mg}$ of total protein/mL for MON810, Bt11, $\mathrm{Bt} 176$, and control samples; approximately $3 \mathrm{mg}$ of total protein $/ \mathrm{mL}$ for T25 and control samples; and approximately $3.5 \mathrm{mg}$ of total protein/mL for Roundup Ready [RUR] and control samples).

For the IgE immunoblot reactivity assay conducted with sera from patients with food allergy, we used an extract prepared with food to which the person undergoing the test was allergic as a positive control extract. Four grams of food material was homogenized in liquid nitrogen and precipitated with $20 \mathrm{~mL}$ of $10 \%$ trichloroacetic acid (wt/vol) in cold acetone containing $20 \mathrm{mM}$ dithiothreitol for 1 hour at $-20^{\circ} \mathrm{C}$. The precipitate was collected by means of centrifugation (15 minutes at $14,000 \mathrm{~g}$ at $4^{\circ} \mathrm{C}$ ), washed twice with $20 \mathrm{mM}$ dithiothreitol in cold acetone, and allowed to dry completely.

\section{Quality of transgenic proteins in maize and soya extracts}

ELISA GMO Check Bt maize test kit (SDI Europe, London, United Kingdom) was used to evaluate the presence-absence of Bt CryIA(b) protein in the lyophilized extracts prepared by Laboratorios Leti. Ten milligrams of dry extract was resuspended in $200 \mu \mathrm{L}$ of the kit extraction buffer provided, and all nonsoluble material was removed by means of centrifugation (10 minutes at $11,000 \mathrm{~g}$ ). The manufacturer's instructions were followed thereafter, using approximately $200 \mu \mathrm{g}$ of total protein.

To evaluate the presence or absence of CP4 5-enolpyruvylshikimate-3-phosphate synthase (CP4EPSPS) protein in RUR soya and nontransgenic analogues, the lyophilized materials were tested with an ELISA GMO Check RUR Soya Grain test kit (Strategic Diagnostics Inc). Five milligrams of dry extract was diluted in $200 \mu \mathrm{L}$ of kit extraction buffer. The nonsoluble material was removed by means of centrifugation (10 minutes at 11,000g). The manufacturer's instructions were followed thereafter, using approximately $2.5 \mu \mathrm{g}$ of total protein.

Thirty micrograms of each sample was also run by means of SDS-PAGE and immunobloted with rabbit anti-Bt CryIA(b) polyclonal antibodies (RDI, Flanders, NJ) or goat anti-CP4EPSPS serum (Monsanto Co, St Louis, Mo; see description below).

It was impossible to obtain commercial anti-phosphinotricine acetyl transferase (anti-PAT) antibodies, and there is no commercially available ELISA kit for PAT. We therefore decided to use the Trait LL corn grain test kit (Strategic Diagnostics Inc) to evaluate the presence or absence of PAT in Bt176, Bt11, T25, and nontransgenic analogues. This kit uses PAT-specific antibodies coupled to a color reagent and incorporated into strips, allowing the detection of PAT in an extract through color development. Ten milligrams of lyophilized samples was diluted in the kit buffer provided, and $100 \mu \mathrm{L}$ of each sample (approximately $200 \mu \mathrm{g}$ of total protein) was eluted along the strip.

For protein quantification, the Bio-Rad protein assay (Bio-Rad laboratories) was used, with turkey albumin (Merck) as a standard.

\section{Skin testing of the $\mathbf{2}$ populations}

Skin tests were performed in 2 human populations with positive histories of food allergy, inhalant allergy, or both, as well as a positive SPT response for related allergens; one group was composed of 27 children with food and inhalant allergy from the Paediatrics Allergy Department of the Hospital of Santa Maria, and the other was composed of 50 patients with asthma-rhinitis from the University Clinic of Pneumology from the Hospital of Santa Maria (see Tables E1 and E2 in the Online Repository in the online version of this article at www.mosby.com/jaci). The children were tested with the extracts of Bt176, Bt11, RUR, and nontransgenic analogues; for the asthma-rhinitis population, we used the extracts of MON810, T25, and nontransgenic analogues for testing (Table I).

Skin tests were performed by using the prick procedure, ${ }^{19}$ and results were read after 20 minutes. The results were classified as positive when the larger diameter of the wheal exceeded $3 \mathrm{~mm}$. Histamine hydrochloride, $10 \mathrm{mg} / \mathrm{mL}$ (Leti), was used as a positive control, and Phenolate saline serum with glycerine (Leti) was used as a negative control.

All the protein extracts were first tested on a control population of 20 nonallergic healthy individuals.

\section{Sera for the IgE immunoblot reactivity assay}

Patient sera were provided by the Joaquim Chaves Clinic and were obtained from 57 individuals who had a positive history of documented food allergy, as well as a positive value equal to or higher than class 3 on specific UniCAP test (Pharmacia Diagnostics, Seixal, Portugal; see Table E3 in the Online Repository in the online version of this article at www.mosby.com/jaci). All 57 sera were first assayed for reactivity against nontransgenic maize and soya by means of specific IgE UniCAP testing. The sera were then tested for IgE immunoblot reactivity against Bt11, Bt176 maize, and RUR soya, as well as against nontransgenic analogues (Table I). MON810 maize and its nontransgenic analogue, as well as pure CryIA(b) (Research Diagnostics, Inc) and CP4EPSPS (Monsanto Co), were used to test the $\operatorname{IgE}$ immunoblot reactivity of sera of the 24 more sensitive patients (Table I).

\section{SDS-PAGE and protein transfer to nitrocellulose membranes}

Samples were diluted 1:2 in sample buffer $(0.125 \mathrm{M}$ Tris- $\mathrm{HCl}[\mathrm{pH}$ 6.8 ], $4 \%$ SDS, $20 \%$ vol/vol glycerol, $0.2 \mathrm{M}$ dithiothreitol, and $0.02 \%$ bromophenol blue) and boiled for 5 minutes before electrophoresis in a 0.75 -mm-thick $10 \%$ acrylamide gel with $4 \%$ stacking gel. ${ }^{20}$ After electrophoresis, the proteins were blotted onto hybond ECL nitrocellulose membranes (Amersham Biosciences, Carnaxide, Portugal) by means of wet transfer in $25 \mathrm{mM}$ Tris, $192 \mathrm{mM}$ glycine, $0.1 \%$ SDS, and $20 \%$ methanol for 1 hour at $75 \mathrm{~V}$ at room temperature.

\section{IgE immunoblot reactivity assay of sera from patients with food allergy}

The detection of patient sera IgE reactivity was carried out after electrophoresis of $30 \mu \mathrm{g}(60 \mu \mathrm{g} / \mathrm{cm}$ gel width) of MON810, Bt11, Bt176, and RUR transgenic samples and nontransgenic analogues and $25 \mathrm{ng}(50 \mathrm{ng} / \mathrm{cm}$ gel width) of pure CryIA(b) and CP4EPSPS and transfer to nitrocellulose membrane.

Blots were blocked overnight at $4^{\circ} \mathrm{C}$ with PBS-T $(58 \mathrm{mM}$ $\mathrm{Na}_{2} \mathrm{HPO}_{4}, 17 \mathrm{mM} \mathrm{NaH} \mathrm{PO}_{4} \cdot \mathrm{H}_{2} \mathrm{O}, 68 \mathrm{mM} \mathrm{NaCl}$, and $0.2 \%$ Tween 
TABLE II. Results of the food inquiry regarding the probability of an individual having consumed a transgenic maize or soya sample

\begin{tabular}{|c|c|c|c|c|c|}
\hline & \multirow[b]{2}{*}{$\mathbf{n}$} & \multicolumn{2}{|c|}{$\begin{array}{c}\text { Mean number of consumed } \\
\text { products with maize or soya } \\
\text { ( } \lambda \text { estimates) }\end{array}$} & \multicolumn{2}{|c|}{$\begin{array}{l}\text { Probability of consumption of products } \\
\text { with transgenic protein }\end{array}$} \\
\hline & & & $95 \% \mathrm{Cl}$ & $P=.235$ & $95 \% \mathrm{Cl}$ \\
\hline Total & 106 & 39.3 & $35.2-43.4$ & 0.999902 & 0.99974-0.99999 \\
\hline \multicolumn{6}{|l|}{ Sex } \\
\hline Male & 48 & 34.8 & $29.2-40.4$ & 0.999959 & $0.99895-0.99993$ \\
\hline Female & 58 & 43.0 & $37.1-48.2$ & 0.999719 & 0.99983-0.99999 \\
\hline \multicolumn{6}{|c|}{ Age group (y) } \\
\hline$<5$ & 20 & 29.5 & $22.6-36.3$ & 0.999024 & 0.99506-0.99980 \\
\hline $5-10$ & 56 & 41.1 & $35.2-46.9$ & 0.999936 & 0.99974-0.99998 \\
\hline $10-25$ & 11 & 48.8 & $35.6-62.0$ & 0.999990 & $0.99976-1.00000$ \\
\hline$\geq 25$ & 19 & 38.9 & $27.5-50.3$ & 0.999893 & 0.99844-0.99999 \\
\hline
\end{tabular}

$n$, Number of valid responses; $P$, probability of one product with maize or soya having transgenic proteins (Instituto de Biologia Experimental e

Tecnológica Good Laboratory Practices Microbiology laboratory data).

20 ) and 5\% skimmed milk powder (or 3\% BSA for patients with milk allergy) and washed with PBS-T before incubation in serum diluted 1:10 in blocking solution for 1 hour and 30 minutes at room temperature. After washing with PBS-T, the membranes were incubated for 1 hour at room temperature in alkaline phosphataseconjugated monoclonal anti-human IgE (Southern Biotechnology Associates, Birmingham, Ala) diluted 1:2000 in blocking solution, washed with PBS-T and assay buffer, and incubated for 5 minutes with CDP-Star solution with Nitro-Block II enhancer (Tropix Western-Star Immunodetection System).

Blots were observed after exposure (5 seconds-30 minutes) to a high-performance chemiluminescence Hyperfilm ECL (Amersham Biosciences).

\section{Immunoblot detection of $\mathrm{Bt} \mathrm{CryIA(b)}$ and CP4EPSPS}

The procedure was identical to the one described for IgE immunobloting of patient's sera, with the following differences. For Bt CryIA(b), the first antibody incubation was performed in rabbit anti-Bt CryIA(b) polyclonal (Research Diagnostics, Inc) diluted 1:1400 in blocking solution, and the second antibody incubation was performed in goat anti-rabbit IgG-AP conjugate (Tropix-Applied Biosystems, Porto, Portugal) diluted 1:2800 in blocking solution. For CP4EPSPS, the first antibody incubation was performed in goat antiCP4EPSPS serum (Monsanto Co) diluted 1:5000 in blocking solution, and the second antibody incubation was performed in anti-goat IgG-alkaline phosphatase conjugate (Sigma, Sintra, Portugal) diluted 1:2500 in blocking solution.

\section{Statistical analysis}

To estimate the probability of one individual from the Portuguese population having once been in contact with transgenic proteins present in maize or soya foods, we used (1) the results from the food inquiry and (2) the percentage data of maize and soya products with detectable transgenic proteins provided by Instituto de Biologia Experimental e Tecnológica Good Laboratory Practices Microbiology laboratory. This laboratory is one of the 2 national laboratories responsible for food GMO detection.

Assuming that the number of products with maize or soya consumed by the population is a Poisson random variable with the expected value $\lambda$ and that the probability of an individual having consumed a product with transgenic proteins (provided he or she had consumed $\mathrm{n}$ products with maize or soya) is modeled by using binomial distributions ${ }^{21}(\mathrm{n}=$ number of experiences, $\mathrm{p}=$ probability of one product with maize or soya having transgenic proteins), we can then calculate the probability of one individual having been in contact with transgenic proteins, which is $1-e^{-\lambda p}$.

To estimate this probability, we used as $\lambda$ the mean number of consumed products with maize or soya obtained in the survey, and as $\mathrm{p}$ the proportion of maize and soya products detected with transgenic proteins calculated by using the Instituto de Biologia Experimental e Tecnológica Good Laboratory Practices Microbiology laboratory data during the last 2 years.

\section{RESULTS}

\section{Food inquiry}

All 106 individuals participating in this inquiry consumed some of the 205 products presented. The extreme cases, with lower and higher numbers of consumed products, were relative to a 1-year-old and 9-year-old girl with 4 and 129 consumed products, respectively. The mean of consumed products with maize and soya was 39.3 (95\% CI, 35.2-43.4), and the probability of an individual having eaten GM food was near $100 \%$ (Table II).

\section{Transgenic quality of the noncertified flour samples}

All 6 tested samples (Bt176, T25, MON810, and the nontransgenic analogues) showed the expected bands when checking for amplifiable maize DNA (data not shown), and only the 3 transgenic samples showed the expected amplicon of the $35 \mathrm{~S}$ promoter (data not shown).

The final confirmation that all the samples tested were correctly labeled and that there was no cross-contamination among them was obtained from construct-specific PCR (Fig 1). As expected, the digestion of the obtained amplicons confirmed the accuracy of the specific PCR (data not shown).

\section{Quality of transgenic proteins in maize and soya extracts}

As described in the Methods section, Laboratorios Leti protein extracts were tested for the presence of the 


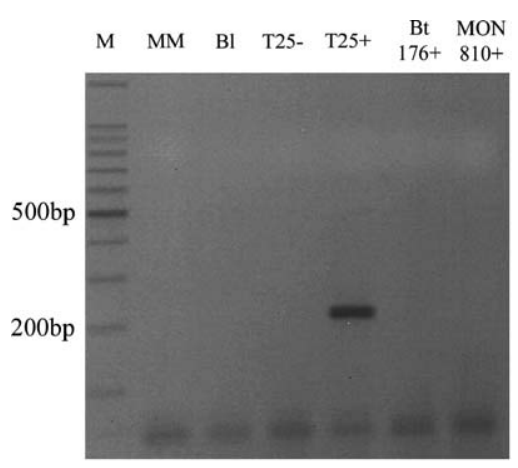

T25 maize

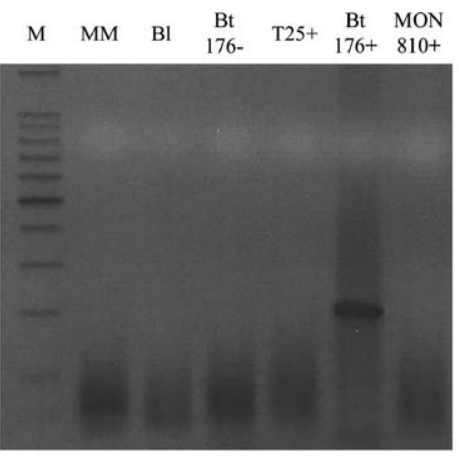

Bt176 maize

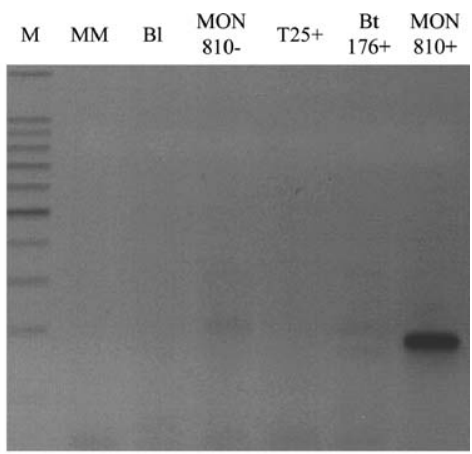

MON810 maize

FIG 1. Construct-specific PCR for the detection of modified DNA sequences from T25, Bt176, and MON810 maize. $M$, 100-bp DNA ladder; $M M$, Mastermix; BI, DNA extraction blank; T25-, Bt176-, MON810-, non-GM controls; T25+, Bt176+, MON810+, 100\% GM T25, Bt176, and MON810 maize, respectively.

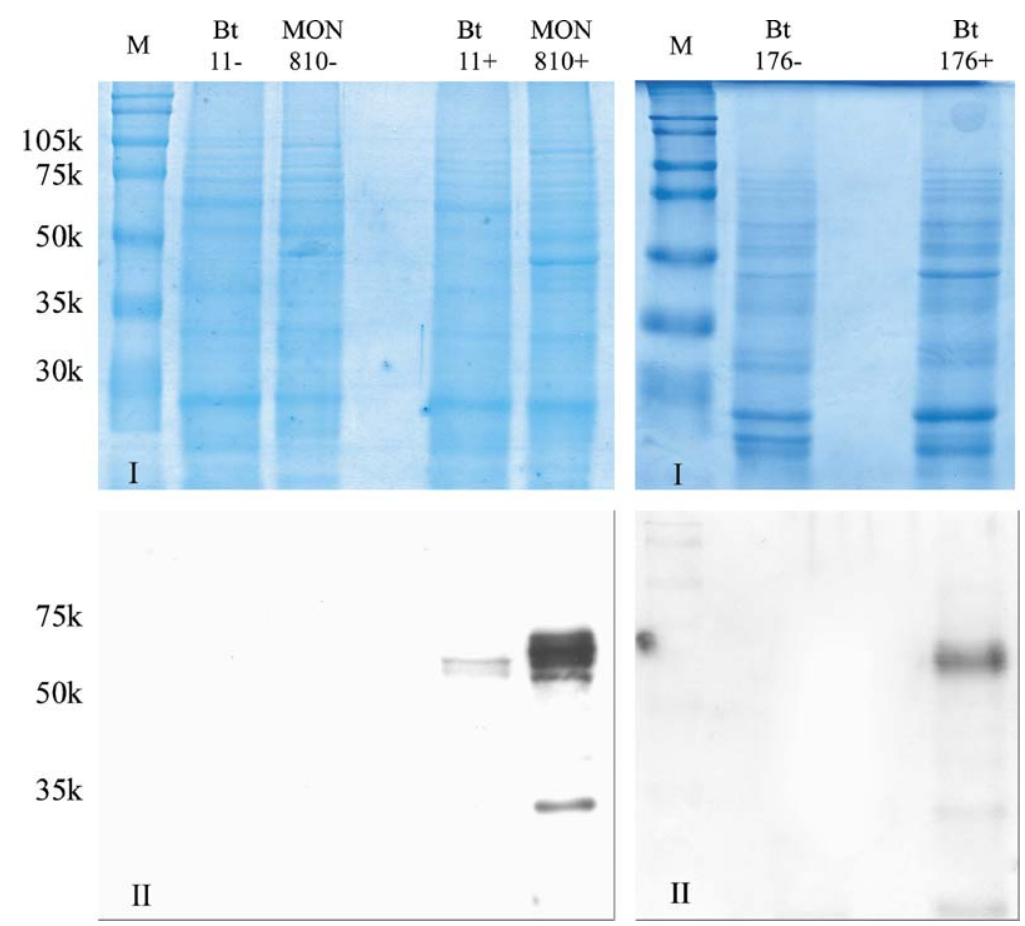

FIG 2. Western blot for the detection of CrylA(b) protein in Laboratorios Leti protein extracts. I, $10 \%$ Acrylamide SDS-PAGE; II, immunoblot with rabbit anti-Bt CrylA(b) polyclonal. $M$, Molecular weight marker; Bt11-, MON810-, Bt176-, non-GM controls; Bt11+, MON810+, Bt176+, GM material 2\% Bt11, 100\% MON810, and $100 \%$ Bt176, respectively.

transgenic proteins under testing. CryIA(b) was detected by using ELISA (data not shown) and Western blotting (Fig 2) in MON810, Bt11, and Bt176 extracts and was absent from the nontransgenic control analogues. CP4EPSPS was also detected by means of ELISA (data not shown) and Western blotting (Fig 3) in RUR extract and was absent from the nontransgenic analogue. Both pure CryIA(b) and CP4EPSPS proteins were detected with the respective specific antibodies (data not shown).

In T25, Bt11, and Bt176 samples PAT protein was detected in $200 \mu \mathrm{g}$ of total protein solutions by using the
Trait LL corn grain test kit. With this system, we have also confirmed the absence of PAT in nontransgenic analogues (data not shown).

\section{Allergenicity tests}

Skin testing of the 2 populations. Only individuals with maize sensitivity, soybean sensitivity, or both had positive results against the protein extracts under testing; however, none of the volunteers reacted differentially to GM versus non-GM samples (Table III and Tables E1 and E2 in the Online Repository in the online version of this article at www.mosby.com/jaci). 

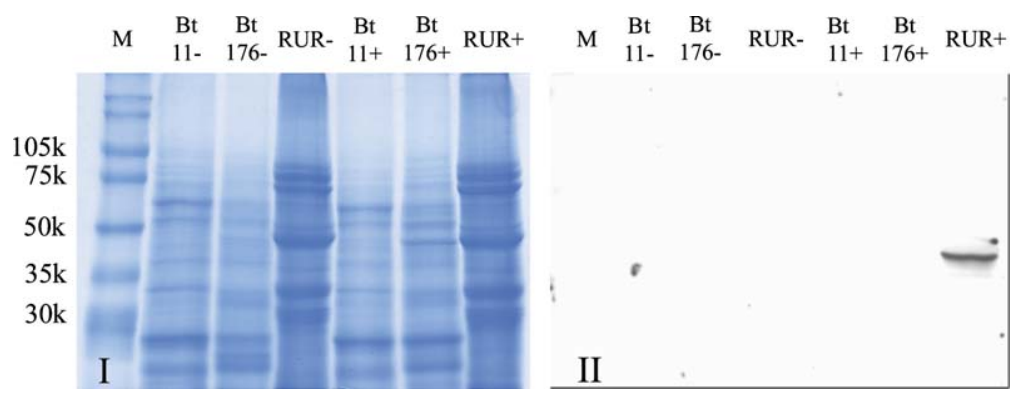

FIG 3. Western blot for the detection of CP4EPSPS protein in Laboratorios Leti protein extracts. $I, 10 \%$ Acrylamide SDS-PAGE; $I I$, immunoblot with anti-CP4EPSPS goat serum (IgG). $M$, Molecular weight marker; Bt11-, Bt176-, RUR-, non-GM controls; Bt11+, Bt176+, RUR+, GM material $2 \% \mathrm{Bt} 11,100 \% \mathrm{Bt} 176$, and $5 \%$ RUR, respectively.

TABLE III. Results obtained with the allergenicity tests performed by using SPTs and IgE immunoblot reactivity assays

\begin{tabular}{lccccc}
\hline & \multicolumn{2}{c}{ SPTs } & & \multicolumn{2}{c}{$\begin{array}{c}\text { IgE immunoblot } \\
\text { reactivity assay }\end{array}$} \\
\cline { 2 - 3 } \cline { 5 - 6 } & $\begin{array}{c}\text { No. of } \\
\text { individuals } \\
\text { tested }\end{array}$ & $\begin{array}{c}\text { Positive } \\
\text { responses } \\
\text { (\%) }\end{array}$ & & $\begin{array}{c}\text { No. of } \\
\text { individuals } \\
\text { tested }\end{array}$ & $\begin{array}{c}\text { Positive } \\
\text { responses } \\
(\%)\end{array}$ \\
\hline GM protein & & & & & \\
PAT & 77 & 0 & & NT & - \\
CRY1A(b) & 77 & 0 & & 57 & 0 \\
CP4EPSPS & 27 & 0 & & 57 & 0 \\
\hline
\end{tabular}

$N T$, Not tested.

All the patients had wheals larger than $3 \mathrm{~mm}$ for histamine, and none of them reacted against the negative control.

IgE Immunoblot reactivity assay of sera from patients with food allergy. Two types of Western blotting results (Figs 4 and 5) were observed. In Fig 4 serum from an individual with octopus allergy of class 4 on specific UniCAP testing reacted only against positive controls. In Fig 5, concerning an individual with peanut allergy of class 6 on a specific UniCAP test, positive signals were observed against the positive control but also against other maize and soya protein extracts.

None of the volunteers tested presented differential signals against nontransgenic versus transgenic protein extracts (Table III). All 24 individuals tested against pure transgenic proteins (CP4EPSPS and CryIAb) presented no detectable reactions against these controls.

\section{DISCUSSION}

Although absolute certainties regarding GM food risks to health and the environment will hardly be obtained, reports regarding potential problems have raised public concern. Some of the concerning issues include the putative toxicity-allergenicity of crops expressing foreign proteins, ${ }^{22-25}$ although these fears have not been confirmed in some later studies, ${ }^{26,27}$ and the adequacy of the methods of testing have been questioned. ${ }^{28}$ Considering that the past few decades have witnessed a significant increase in IgE-mediated allergic diseases, the allergenic potential of these novel foods is a major concern in public health.

The food inquiry performed in this study indicated that the probability of an individual having eaten GM food was near $100 \%$ (Table II). This value is probably underestimated because each individual probably consumed each product several times, which was not considered in statistical calculations.

Also, it is possible that the first sensitization occurred during breast-feeding in the individuals submitted to SPTs and Western blot analyses who were younger than 6 years (the time between the first commercialization in 1998 and 2004). ${ }^{29}$ It therefore seems reasonable to assume that all the individuals participating in this study had already been in contact with the products tested.

The DNA and protein quality analysis performed in this study confirmed the quality of flour samples and maize and soya protein extracts (Figs 1-3). In the Western assay for the detection of CryIA(b) in Bt11, Bt176, MON810, and nontransgenic control analogues (Fig 2), the multiple bands approximately equal to the CryIA(b) trypsin resistant core observed are likely the products of endogenous grain proteases. ${ }^{30}$ Some of the protein is degraded further to produce lower-molecular-weight bands, including a $30-\mathrm{kd}$ product previously reported. ${ }^{30}$

As already mentioned, we have performed this study on sensitive populations. The population submitted to SPTs and immunoblot analyses was composed of individuals with food allergy and inhalant allergy, many of them children. Children are more susceptible to food allergies than adults. This higher susceptibility is probably the result of immunologic immaturity and, to some extent, immaturity of the gut. ${ }^{31,32}$ In addition, children who have preexisting food allergies are more likely to experience allergic reactions to other foods introduced in their diets.

The absence of detectable differences in IgE reactivity between GM maize and soya samples and the corresponding wild-type samples obtained in this study is in accordance with some previously published results. ${ }^{33,34}$

The appearance of nondifferential bands on some chemiluminescence films for maize and soya protein 

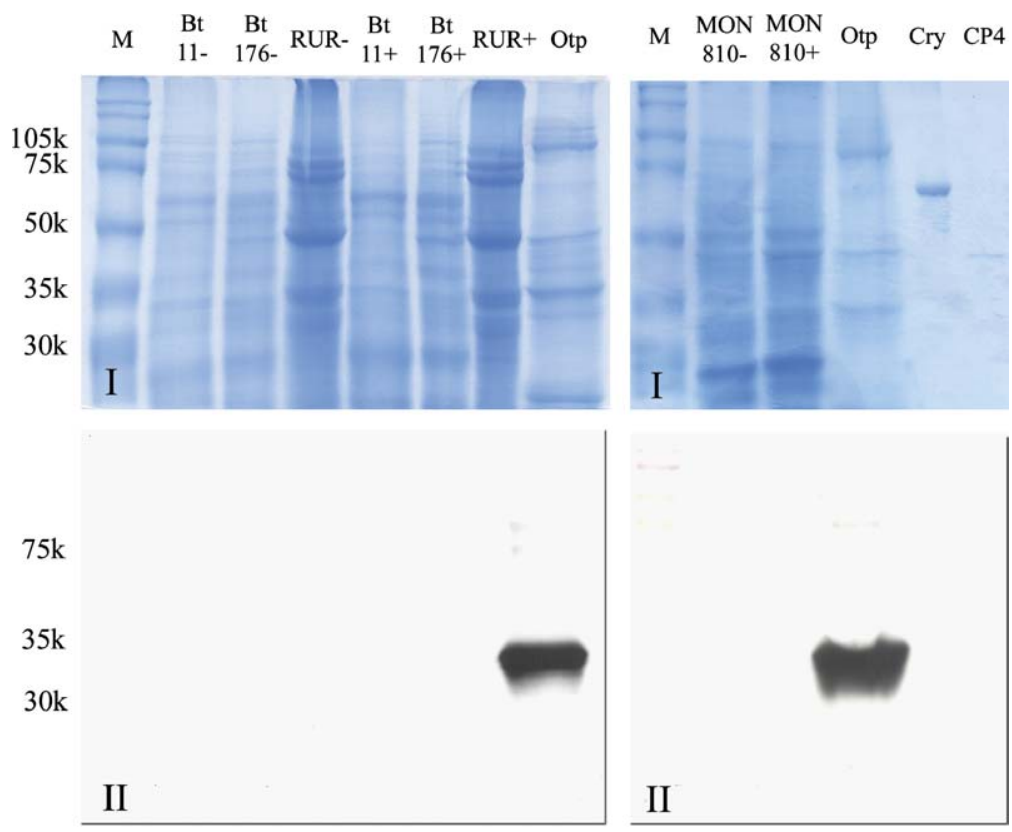

FIG 4. IgE antibody reactivity assay from an octopus-sensitive patient. $I, 10 \%$ Acrylamide SDS-PAGE; II, immunoblot. $M$, Molecular weight marker; Bt11-, Bt176-, RUR-, MON810-, non-GM controls; Bt11+, Bt176+, RUR+, MON810+, GM material 2\% Bt11, 100\% Bt176, 5\% RUR, and 100\% MON810, respectively; Otp, Octopus protein extract; $C r y$, CrylA(b); CP4, CP4EPSPS.

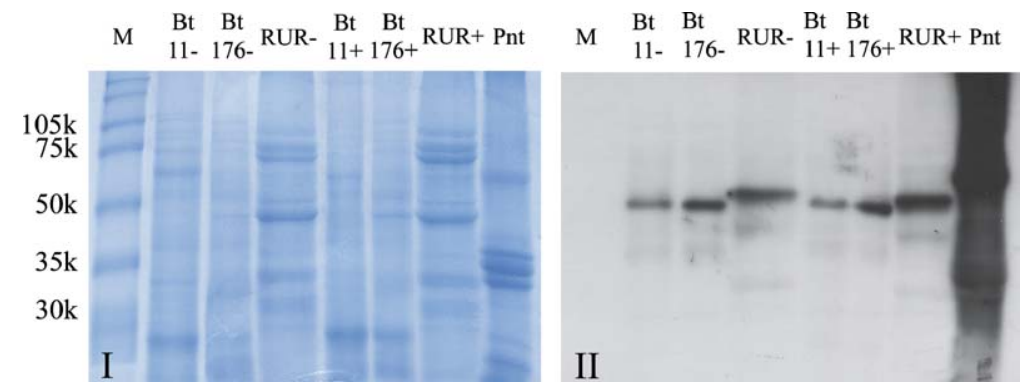

FIG 5. IgE antibody reactivity assay from a peanut-sensitive patient. $I, 10 \%$ Acrylamide SDS-PAGE; II, immunoblot. $M$, Molecular weight marker; Bt11-, Bt176-, RUR-, non-GM controls; Bt11+, Bt176+, $R U R+$, GM material 2\% Bt11, 100\% Bt176, and 5\% RUR, respectively; Pnt, Peanut protein extract.

extract lanes (Fig 5) might be due to the phenomenon of cross-reactivity among various plant and animal proteins. ${ }^{35,36}$ In the example presented in Fig 5, although the patient tested had only documented peanut allergy (class 6 on UniCAP test), it was shown that he also had IgE binding to other foods, such as almond (class 2), hazelnut (class 3), walnut (class 2), cashew (class 4), soybean (class 3), and maize (class 3). This fact justifies the appearance of the nondifferential bands on maize and soya lanes.

Although IgE detection (either SPT or specific IgE) serves as a good indicator of sensitization but not necessarily of disease, in the clinical setting the absence of detectable $\operatorname{IgE}$ was found to have excellent negative predictive accuracy indices and therefore might be very useful in excluding the presence of immediate food hypersensitivity. ${ }^{37}$
In this study we did not obtain any differential positive results, which allows us to conclude that the transgenic products under testing seem to be safe regarding their allergenic potential. Although we succeeded in integrating a private clinic and a hospital in this study, it would be desirable to increase the size of the analyzed population and eventually extend this work to other countries.

We also propose the development and use of clinical testing with specific IgE in the postmarketing surveillance of foods produced through biotechnology. Positive test results should be followed by double-blind, placebocontrolled food challenges under appropriate clinical observation to identify true clinical reactions. ${ }^{38}$

We gratefully acknowledge the National Service of Plant Protection (DGPC) for providing BT176, T25, MON810, and nontransgenic analogue maize samples; Laboratorios Leti for the 
preparation of maize and soya protein extracts; and Monsanto, especially Dr Richard Goodman, for providing the CP4EPSPS protein and the corresponding antiserum. Fernanda Spínola and Cátia Peres are gratefully acknowledged for their advice regarding GMO detection. We also thank Margarida Santos, Helena Raquel, Madalena Martins, and Sara Silva for help in the preparation of the food inquiry. Finally, we thank Phil Jackson for the final revision of the manuscript and Fundação Calouste Gulbenkian and Comissão de Fomento da Investigação em Cuidados de Saúde for funding.

\section{REFERENCES}

1. Alam MF, Datta K, Abrigo E, Vasquez A, Senadhira D, Datta SK. Production of transgenic deepwater indica rice plants expressing a synthetic Bacillus thuringiensis cryIA(b) gene with enhanced resistance to yellow stem borer. Plant Sci 1998;135:25-30.

2. Shintani D, Della Penna D. Elevating the vitamin E content of plants through metabolic engineering. Science 1998;282:2098-100.

3. De la Fuente JM, Ramirez Rodriguez V, Cabrera Ponce JL, Herrera Estrella L. Aluminium tolerance in transgenic plants by alteration of citrate synthesis. Science 1997;276:1566-8.

4. Ye X, Al Babili S, Kloeti A, Zhang J, Lucca P, Beyer P, et al. Engineering the provitamin A (beta-carotene) biosynthetic pathway into (carotenoid-free) rice endosperm. Science 2000;287:303-5.

5. Goto F, Yoshihara T, Shigemoto N, Toki S, Takaiwa F. Iron fortification of rice seed by soybean ferritin gene. Nat Biotechnol 1999;17:282-6.

6. Nordlee JA, Taylor SL, Townsend JA, Thomas LA, Bush RK. Identification of a Brazil-nut allergen in transgenic soybeans. N Engl J Med 1996;334:688-92.

7. Matsuda T, Nakamura R. Molecular structure and immunological properties of food allergens. Trends Food Sci Technol 1993;4:289-93.

8. Taylor SL, Leher SB. Principles and characteristics of food allergens. Crit Rev Food Sci Nutr 1996;36(suppl):S91-118.

9. Sampson HA. Food Allergy. JAMA 1997;278:1888-94

10. Anderson JA. Allergic reactions to foods. Crit Rev Food Sci Nutr 1996; 36(suppl):S19-38.

11. Bock SA. Prospective appraisal of complaints of adverse reactions to foods in children during the first three years of life. Paediatrics 1987;79: 683-8.

12. Helm RM, Burks AW. Mechanisms of food allergy. Curr Opin Immunol 2000; 12:647-53.

13. Metcalfe DD, Astwood JD, Townsend R, Sampson HA, Taylor SL, Fuchs RL. Assessment of the allergenic potential of foods derived from genetically engineered crop plants. Crit Rev Food Sci Nutr 1996; 36(suppl):S165-86.

14. Mendieta NLR, Nagy AM, Lints FA. The potential allergenicity of novel foods. J Sci Food Agric 1997;75:405-11.

15. Taylor SL. Assessment of the allergenicity of genetically modified foods. Nutr Abstracts Rev (Series A) 1997;67:1163-8.

16. Lack G, Chapman M, Kalsheker N, King V, Robinson C, Venables K. Report on the potential allergenicity of genetically modified organisms and their products. Clin Exp Allergy 2002;32:1131-43.

17. Draft International Standard ISO/DIS 21571. Foodstuffs-methods of analysis for the detection of genetically modified organisms and derived products-nucleic acid extraction. Nov 2002. p. 25-8.

18. Draft International Standard ISO/DIS 21569. Foodstuffs-methods of analysis for the detection of genetically modified organisms and derived products—qualitative nucleic acid based methods. Nov 2002. p. 23-66.

19. Sub-Committee on Skin Tests of the European Academy of Allergology and Clinical Immunology. Skin tests used in type I allergy testing. Allergy 1989;44(suppl 10):1-59.

20. Laemmli UK. Cleavage of structural proteins during the assembly of the head of bacteriophage T4. Nature 1970;227:680-5.

21. Bliss CI. Statistics in biology. Vol 1. New York: MacGraw-Hill; 1967. p. 558.

22. Losey JE, Rayon LS, Carter ME. Transgenic pollen harms monarch larvae. Nature 1999;395:214.

23. Ewen SWB, Pusztai A. Effect of diets containing genetically modified potatoes expressing Galanthus nivalis lectin on rat small intestine. Lancet 1999;354:1353-4.

24. Taco Bell taco shells sold in grocery stores contain banned corn [transcript]. CNN. September 18, 2000. Available at: http://europe.cnn.com/2000/ FOOD/news/09/18/food.corn.reut/. Accessed January 10, 2005.

25. EPA Assessment of Scientific Information concerning Starlink Corn Cry9C Bt Corn Plant-pesticide. Federal Register 65 (October 31, 2000). Environmental Protection Agency publication no. 65246-65251. Available at: http://www.access.gpo.gov/su_docs/fedreg/frcont00.html. Accessed January 10, 2005.

26. Sears MK, Hellmich RL, Stanley-Horn DE, Oberhauser KS, Pleasants JM, Matilla HR, et al. Impact of Bt corn pollen on monarch butterfly populations: a risk assessment. Proc Natl Acad Sci U S A 2001;21: 11937-42.

27. Sutton SA, Assa'ad AH, Steinmetz C, Rothenberg ME. A negative, double-blind, placebo-controlled challenge to genetically modified corn. J Allergy Clin Immunol 2003;112:1011-2.

28. Kuiper HA, Noteborn HPJM, Peijnenburg ACM. Adequacy of methods for testing the safety of genetically modified foods. Lancet 1999;354: 1315-6.

29. Vadas P, Wai Y, Burks W, Perelman B. Detection of peanut allergens in breast milk of lactating women. JAMA 2001;285:1746-8.

30. Miranda R, Zamudio FZ, Bravo A. Processing of Cry1Ab $\delta$-endotoxin from Bacillus thuringiensis by Manduca sexta and Spodoptera frugiperda midgut proteases: role in protoxin activation and toxin inactivation. Insect Biochem Mol Biol 2001;31:1155-63.

31. Sampson HA, Metcalfe DD. Food allergies. JAMA 1992;268:2840-4.

32. Sampson HA. Food allergy. Part 2: diagnosis and management. J Allergy Clin Immunol 1999;103:981-9.

33. Sten E, Skov PS, Andersen SB, Torp AM, Olesen A, Bindslev-Jensen U, et al. A comparative study of the allergenic potency of wild-type and glyphosate-tolerant gene-modified soybean cultivars. APMIS 2004;112: 21-8.

34. Burks AW, Fuchs RL. Assessment of the endogenous allergens in glyphosate-tolerant and commercial soybean varieties. J Allergy Clin Immunol 1995;96:1008-10.

35. Sicherer SH. Clinical implications of cross-reactive food allergens. J Allergy Clin Immunol 2001;108:881-90.

36. Vieths S, Scheurer S, Ballmer-Weber B. Current understanding of crossreactivity of food allergens and pollen. Ann N Y Acad Sci 2002;964: 47-68.

37. Sampson HA, Albergo R. Comparison of results of skin tests, RAST and double-blind, placebo-controlled food challenges in children with atopic dermatitis. J Allergy Clin Immunol 1984;74:26-33.

38. Bindslev-Jensen C, Poulsen LK. Accuracy of in vivo and in vitro tests. Allergy 1998;53:72-4. 